Howe, C. (2009). The Legible Lesbian: Crimes of Passion in Nicaragua. Ethnos, 74(3), 361-378.

http://doi.org/10.1080/00141840903053121

\title{
The Legible Lesbian: \\ Crimes of Passion in Nicaragua
}

\author{
Cymene Howe \\ Rice University, Houston, USA
}

\begin{abstract}
This article considers a precedent-setting murder case in Nicaragua that rendered a conviction based upon the victim's 'sexual option' and status as a 'lesbian.' A significant achievement for advocates in Nicaragua, the case was also a victory for sexual and human rights proponents globally. This article queries how the sexualization of culture can be viewed through the spectacle of Aura Rosa's life, death and symbolic resurrection. Analyzing the discourses and practices of Nicaraguan activists, international rights campaigns, the state, and local media, I argue that the post-mortem process of refiguring the victim as a 'lesbian' is imaginable only within a discursive field saturated with human rights paradigms including those of sexual rights. Central to these practices are notions of vulnerable bodies, ascriptions to particular models of modernity and an emerging 'epistemology of the hate crime.'
\end{abstract}

Keywords: Sexuality, rights, Latin America, hate crime, lesbian

A murder is committed. Why? To get another man's wife or wealth, or to snatch at the necessities of life. Or for fear that someone would deprive the murderer of such things. Or from a sense of wrong burning for redress. Who murders with no motive but the mere murdering?

ST. AUGUSTINE Confessions (2006:33) 
In February 2000, some time during la madrugada — those few hours before dawn - the murdered body of Aura Rosa Pavón was recovered from a pit latrine where it had been dumped. Aura Rosa was a very poor woman, even in the context of Nicaragua, the second poorest country in the western hemisphere. She was generally well-respected in her small rural town and was known for her hard work and perseverance against diffi cult odds. She was also well-known to be a cochona (a 'dyke' and more specifically, a masculine woman). On Christmas day, Aura Rosa was shot twice and killed by the husband of her girlfriend and lover, Karla Muñoz. It was three months later, at the prompting of Aura Rosa's sister, that her corpse was ultimately found and laid to rest. There is, of course, much more to the story. [End Page 361]

Why was Aura Rosa killed? Until recently there have been no recorded incidences of violence against sexual minorities, qua minorities in Nicaragua. However, the country has no dearth of 'crimes of passion' that often unfold in the sucesos (happenings) columns of nationally circulated newspapers. Aura Rosa's story was no less dramatic: it including coerced marriage, poverty, incarceration, jealousy and betrayal. Nicaraguan sexual rights activists charged that the homophobic climate brought about by Nicaragua's then anti-sodomy law (Article 204) considered by Amnesty International to be the most repressive in Latin America - created the conditions in which Aura Rosa could be, and would be, killed for her sexual difference.

According to sexual rights advocates, Aura Rosa was murdered not because she was having an affair with another man's wife, but because she was a lesbian. The murder trial that followed was precedent-setting: it was the first time in Nicaragua that a murder conviction was made on the claim that 'the sexual option of the victim was the motive for the crime' (La Boletina 2004). The man who murdered Aura Rosa, along with his accomplices, were successfully convicted of something akin to a 'hate crime.' This conviction was a significant achievement for sexual rights advocates in Nicaragua, and by extension a victory for lesbian and gay rights and human rights proponents globally. But one might also ask what this victory masks.

Multiple meanings surround Aura Rosa's life, death and semiotic resurrection through activist campaigns, media spectacles and judicial proceedings. Aura Rosa may well have been killed because of her sexual identity, but this does not foreclose how designating 'sexual option' as the motive for this crime may overshadow other criminal intents, other categories of gender and sexuality, and other sorts of quotidian violence. In this article I am interested in how 'sexuality' served as a key semiotic marker in these juridical and activist practices and how an 'epistemology of the hate crime' thus emerged. As human rights and identity politics circulate in transnational terrains, local populations, activists, the state and media outlets work to rearticulate these global discourses and practices into socially and culturally relevant and applicable claims for justice? Unraveling Aura Rosa's story, and the ways in which such spectacles are played out in the realm of the media and the representations of activists, probes the truncated time of the 'eternal present' (Debord 1988). Aura Rosa's story, for one, was transformed from a narrative of perseverance to one of persecution. Through this process, particular ways of speaking about sexuality, culture, and change resulted in new ways of imagining la cochona as la lesbiana. By first focusing on human rights [End Page 362] as a political commodity within the context of Nicaragua's particular sexual epistemologies, this discussion then moves on to the 'rest of the story.' I argue that Aura Rosa was re-figured, post-mortem, as a 'lesbian' through juridical processes, spectacles and advocacy initiatives heavily influenced by human rights paradigms and locally situated iterations of identity politics.

Nicaragua is no longer the hot bed of cold war action that it was in the 1980s. It is a small country that, while it once served as a beacon for Marxist aspirations and popular insurrection in 
the developing world, now largely exists on the margins of global power-broking and influence. Though the Sandinista Party recently re-took the presidency in the 2006 elections, the political and social values which underwrote the country's revolution in 1979 appear radically changed in the present Sandinista regime, including recent political moves to embrace the Catholic Church and neoliberal economic policies. The revolutionary Sandinista state (1979-1990) achieved some of their egalitarian goals, but the revolution was truncated, foiled and failed, as many have observed. During the 1980s a nascent and transnational gay and lesbian movement was founded (Ferguson 1991; Howe n.d.; Randall 1993; Thayer 1997). But it was not until the early 1990s, when the country's anti-sodomy law was augmented, that sexual rights advocates gained traction and found a common enemy in the revitalized repressive apparatus of the state. It was then that the subject of homosexuality per se became a part of the quotidian media of Nicaraguan television, print and radio. ${ }^{1}$ With the advent of sexual rights in Nicaragua, following the global 'women's rights as human rights' campaigns of the 1990s, local activists along with international advocacy organizations have sought to claim sexuality in public and politicized terms. Under the mantles of sexual opción, sexual orientación, lesbiana, gay, and homosexual, practices are being transformed into identities through advocacy practices such as discussion groups for lesbians and gay men and a week-long set of events celebrating a 'sexuality free from prejudice' in late June every year.

The emergence of sexual rights in Nicaragua is indicative of a particular remaking of a moral order in the midst of neoliberal economic strangleholds and socialist dreams deferred. But as Weber might have asked, how does one group of legitimating values give way to another? Was Aura Rosa's murder a hate crime, a crime of passion, or, to put it bluntly, a murder motivated by something akin to a property crime: 'stealing' another man's woman? While activists and attorneys argued that Aura Rosa was murdered because she was a lesbian, one might submit that she was killed because she made cuckold a powerful man; this would be a phenomenon with historical resonance in [End Page 363] Nicaragua. In the past, it has been possible to imagine killing someone who has robbed you of your wife or trespassed on the prerogatives of machismo. It took a stretch of the imagination, however, to envision killing someone for being a lesbian, demanding a particular form of Hegel's 'recognition.' Reading Aura Rosa's case as a 'hate crime' indexes her sexuality as fundamental. But one dimension that is occluded in this boon for sexual rights are more mundane and quotidian harms including routinized violence against women. In Nicaragua nearly one third of women report being physically or sexually abused by their male partners (World Organisation Against Torture 2001).

The legibility of 'sexual identity' presumes a fluency in the transnational registers of human rights and identity politics. Drawing upon human rights paradigms is a way for Nicaraguan advocates to enlist global norms in order to mitigate the effects of a callous state an attempt to render justice by invoking transnational values. Prior to the mid 1980s, the category 'lesbian' was not widely used in Nicaragua. Even at that time, it was a term largely used by transnational, intellectual elites. More substantively, and perhaps more importantly, Nicaragua has not had a history of violence against marked sexual minorities as such. Aura Rosa's tale can only be rendered within the context of global sexual rights, transnationally waged 'culture wars,' and juridical climates where human rights often trump discourses of development and other liberationist strategies (Žižek 2005).

As sexual rights gain further traction around the world, how are moral priorities reordered, or are they? Anthropologists concerned with human rights have sought to unravel some of these thorny theoretical and political problems. On the one hand, the liberal etiology and 
values of human rights (intended to be universally applicable) must be accounted for, but so too must particular cultural distinctions be weighed (Nagengast \& Turner 1997). In the case of Aura Rosa a new legitimacy and legibility was constructed around 'sexuality' as a point of identification. With human rights as the discursive vehicle, sexuality was made into a political commodity as advocates attempted to open new conceptual spaces and create a new legal and social 'consciousness' around sexuality.

\section{A Brief History of Sex and Death}

Any concept of lesbian 'legibility' contains many modes of deciphering sexual categories, social configurations and juridical ecologies in their larger cultural gestalt. Historically, Nicaragua's social lexicon had an 'other' category of sexual subject: la cochona. Many cochonas were (and are) quite visible, or [End Page 364] in North American and European parlance 'out,' in terms of their refusal of gender conformity and sometimes, their romantic lives with other women. They were (and are) largely the object of pity, mockery, confusion and often, deeply ignored (Bolt González 1996; Montenegro 2000). But they have not been figured as particularly hate-able. Though marginalized, cochonas are a part of very quotidian social and familial spaces. 'Every neighborhood,' urban Nicaraguans will say, 'has its cochón ('fag') and cochona.' While I have never met a Nicaraguan who has been expelled from her family home for being a cochona, neither is lesbian sexuality a topic for typical Nicaraguan dinner conversation. In general, cochona is a derogatory term for masculine-appearing women who have sexual and affective relationships with other women (typically 'feminine' women designated as muy mujer or 'very womanish'). But it is also a term that has been, at times, quite neutral. For instance, in the Nicaraguan family households where I have lived during my field research, my visitors were often nonchalantly announced in this way: 'there is a cochona here to see you.' In other words, there is a measured ambivalence about cochonas in public spaces.

In terms of how cochonas represent themselves, Nicaragua has not (yet) seen a reappropriation of historical epithets where monikers such as 'queer,' 'fag' or 'dyke' are selfidentifying markers of pride. I have never encountered a Nicaraguan woman who has declared, 'I am a cochona.' These women, rather, often describe themselves in terms of their social relations, 'I am Eva's partner,' or 'I take care of my mother,' or even, 'I am someone who loves women.' They also often describe themselves in terms of location, 'I am a Masayan' or 'I am from the country.' More recently, with NGOs (largely in urban settings) conducting consciousness-raising groups based on lesbian identity, some women are now adopting the term 'lesbian' to identify themselves. This is a shift toward situating one's self under the sign of sexuality.

Katherine Franke, a critical legal theorist, writes that 'to call something sexual is at once to say too much and not enough about the meaning of a practice so named' (2002:290-91). Following a longstanding debate in feminist politics and scholarship as to what constitutes 'sex crimes,' Franke (2002:320) argues that invariably, if mistakenly, sex crimes are constituted by the 'parts' involved: those bodily locations (genitals, mouths, etc.) that are deemed 'sexual' by whichever cultural logic, power relations and legal apparatuses are speaking. She is concerned with the ways in which certain sites on the body are always already and exclusively made sexual through signification and asks whether these sites may ever exceed or escape this [End Page 365] designation. Deborah Elliston (1995) offers a similar interrogation of whether the 'erotic,' or its nearly coeval cousin in the west, the 'sexual,' is as transparent as some would claim. 
Elliston's critique hinges on the fallacious importation of western value systems concerning the erotic. Her critique, like Franke's, never belies the body; she is concerned with the ways in which putatively erotic organs are rather seamlessly or tautologically rendered as sexual. Just as bodily organs are inscribed as sexual or erotic, processes of signification also imbue larger social phenomenon with sexuality, sometimes occluding other meanings. With a grander conception of the 'body' — as a social body or the body politic — I am asking how it is that particular historical moments and social conditions lend themselves to becoming sites of 'sexuality.' Or, as Foucault plainly put it, how, when and where does sex become 'an especially dense transfer point for relations of power' (Foucault 1990:103) for both living, and dead, bodies?

Nicaragua has been described as a place where there is 'homosexuality with-out a gay world' (Adam 1993). As in many Iberian-influenced postcolonial contexts, Nicaragua reflects a kind of homosexual habitus that social scientists have called 'the Mediterranean model.' In this configuration, which is based on accounts of homosexual acts between men, it is only the 'passive' (or 'feminized') partner in homosexual relations who becomes stigmatized. In Nicaragua he is called a cochón ('fag'). Because of the thin quotient of social scientific analyses of women's same-sex affective relationships in Nicaragua and the rest of Latin America, it is not yet possible to conclude how women might configure in these passive/active paradigms. Writing about Nicaragua in the late 1980s and early 1990s Roger Lancaster noted that 'there is little popular interest in categorizing or regulating female same-sex relations and little exists in the popular lexicon to account for it' (1992:271). However, in my conversations with both rural and urban Nicaraguans from different class backgrounds, from the early 1990s to the present, I have never encountered a Nicaraguan who was not familiar with the term and the personage, cochona. ${ }^{2}$ Cochonas are easily identified because of their hombruna (mannish) ways. But there is also a class of 'very womanish' women (muy mujer ) and femeninas - who have either occasional or exclusive sexual and affective relationships with other women, but who would not consider themselves (nor are they considered by their neighbors, friends, boyfriends or husbands) to be homosexual, cochona, lesbian, bisexual or in any signifi cant way, sexually 'different.' It is only the cochona who garners stigma; her feminine girlfriend is not considered 'queer.' [End Page 366]

Nicaragua is by no means a queer utopia, and to interpret the presence of pink triangles and rainbow stickers strategically located in some urban areas as representing gay liberation would be mistaken. However, the presence of activism on behalf of sexual minorities as well as accusations against them - oscillating between marginalization, mockery, social ambivalence and legitimacy - suggest that Nicaragua can neither be simply defined as a machista, homophobic terrain as some stereotypes might have it. Attempts to affix the status of a 'sexual minority,' whether by the Nicaraguan state through anti-sodomy laws or by gay and lesbian identity advocates, I would argue, does not arise from a fear of the 'uncategorizable' (Butler 2004:34). Rather, the concept of a 'sexual minority' is uncovered through a field of multiple, polysemic and overlapping categories.

\section{The Rest of the Story}

Born in Niquinohomo, the birthplace of Sandino - the martyred hero from whom the Sandinistas drew their name - Aura Rosa was 26 years old when she was killed. ${ }^{3}$ Recognized in her community as a hard-working woman, Aura Rosa was also well known as a cochona. She 
was unapologetic about her attraction to other women and unconcerned with subscribing to gender-appropriate dress codes and the expectations of femininity. Aura Rosa was the kind of woman whom Nicaraguans would designate as mangas largas (long sleeves), for the men's longsleeve shirts that cochonas are said to favor.

Aura Rosa made her living raising pigs and chickens. She was described as muy humilde ('very humble') - a term Nicaraguans use to designate extreme poverty by wrapping it in the euphemism of moral humility. Over time, Aura Rosa managed to purchase a piece of land on which she hand-built a small house. The house was literally hand-built: it was not constructed from the cinder blocks that are common construction material among the working classes, but hand-crafted from river mud mixed with straw and other found materials. It was indeed a humble home. Aura Rosa's intent was to share her home with 'her love:' a young woman named Karla Muñoz. Karla, however, had already been promised to a wealthy coffee plantation owner, Daniel Norori Tapia. Karla's mother, in the hopes of relieving her own family's poverty, had agreed that Karla would marry the 60-year-old Tapia who had been inquiring after Karla since she was 13. Though Karla had become romantically involved with Aura Rosa at some point during her late teens, she did become Tapia's wife.

After Karla's mother sent her to live with Tapia, she continued to meet [End Page 367] with Aura Rosa in secret and their love affair continued. Tapia and Karla's mother soon discovered the two, and both were furious. Collaborating once again, Karla's mother and Tapia phoned the local police and, invoking Article 204, ${ }^{4}$ filed a charge of 'sodomy' against Aura Rosa. Karla was also 'pressured,' according to Aura Rosa's account, to fi le a charge against Aura Rosa along with that submitted by Karla's mother. Under Article 204 the fact that Aura Rosa was older than Karla meant that the prosecutor could argue for an increased sentence based on 'illegitimate seduction' (seducción ilegítima). Based on her putative 'authority' (influencia de autoridad) or 'moral influence' (dirección moral) in the affair, the law states that Aura Rosa would also be the only one accountable for these sexual improprieties.

Aura Rosa was tried under Article 204 and sent to prison. ${ }^{5}$ But she was released after several months when an attorney successfully argued that Karla Muñoz had been pressured by her mother to bring charges against Aura Rosa. Under the tutelage of the attorney, Karla then wrote a letter to the court saying that she 'loved Aura Rosa' and that she [Aura Rosa] had not hurt her in any way; nor had she been raptada ('kidnapped' or 'abducted') by her. One condition of her early release was that Aura Rosa cease contact with Karla Muñoz. Karla was now spending all of her time in Tapia's household, by some accounts she was, 'imprisoned.'

But, the women's love affair continued. Through the well-oiled channels of local gossip, Karla's mother and Tapia soon got word of their reunification and decided to elicit the support of Karla's cousin in an effort to separate the lovers. Their relationship, after all, both fouled Karla's mother's well-laid plans for conjugal support, and made Tapia a cuckolded husband - not at the hands of another man, but a woman who dared to transgress the terrains of masculine prerogative. Karla's cousin, as the newly recruited accomplice, crafted a romantic note, invoking details that he had gleaned from conversations with Karla while in her confidence. The note, supposedly from Karla, and legitimated because it was hand-delivered to Aura Rosa by the trusted cousin, requested that Aura Rosa meet Karla in the woods on Christmas night. Aura Rosa went to the meeting place and was summarily shot by Tapia. Her body was then tossed into the pit latrine - a way of disposing of bodies that evokes Somoza-era punishments for those opposed to the authoritarian regime. ${ }^{6}$ [End Page 368] 


\section{Post Mortems and Modern Love}

The public manifestation of Aura Rosa's murder began soon after she had gone missing. Aura Rosa's sister, who worked as a maid in the capital, became desperate for information about Aura Rosa once she realized her sister was missing and posted a notice about Aura Rosa's disappearance. Appearing in the widely read national newspaper, El Nuevo Diario, the notice criticized the local police for ignoring the case. It was likely because of this media exposure that Aura Rosa's body was eventually found - though reportedly her body was found 'by coincidence. $^{\text {, }}$

At the same time the media focused attention on Aura Rosa's murder, other iterations of sex and sexuality were on most everyone's mind in Nicaragua. Two years prior, Zoilamérica Narvaez, the adopted daughter of Daniel Ortega (Sandinista president during the Revolutionary era - who is now President again) made national and international headlines when she publicly denounced Ortega for allegedly having molested her since the age of 11 . The 'daughter of the revolution,' as Zoilamérica was affectionately known throughout the 1980s, filed a public denouncement that was picked up by the national newspapers. The media fray ultimately resulted in a serialized 50-page testimony detailing sexual assaults that Ortega had allegedly carried out during his years as Nicaragua's head of state. With the support of friends and feminist advocates, Zoilamérica filed a case in the Inter-American Court of Human Rights. Zoilamérica's accusations, re-invigorated by political rivalry and feminist activists during the presidential election campaign of 2000, was a source of much speculation and political positioning on street corners and in Nicaragua's daily diet of print capital and televised news.

Similar forms of sensationalism and tabloid titillation became essential to the media's representation of Aura Rosa's murder, trial and sentencing, situated as they were in newly overt discussions about sex, propriety and morality. In the press coverage of Aura Rosa's murder and ensuing trial she was depicted in sexualized terms, following suit with the scandal that had been wrought through Zoilamérica's allegation. Headlines proclaiming, 'Lesbian led tormented life' (El Nuevo Diario, February 27, 2000) 'Trial begins for lesbian murder' (El Nuevo Diario February 23, 2000) and 'All guilty in lesbian murder' (La Prensa June 28, 2000) were featured on the front pages of the nationally circulated papers. Articles detailed what many sexuality activists considered 'morbid details' about her life and death. All of the headlines placed Aura Rosa squarely under the sign of 'lesbian.' [End Page 369]

No longer a humble woman or a cochona from Niquinohomo, Aura Rosa had been resurrected as 'the lesbian.' While newspaper accounts consistently referred to Aura Rosa as 'the lesbian,' her lover, Karla, was simply called the 'young one' (la jovencita) or 'the promised woman' (la mujer prometida). Both Karla and Aura Rosa were involved in a 'lesbian,' or samesex affective and sexual relationship, but only Aura Rosa emerged with the designation 'lesbian.' Importantly, it was only Aura Rosa who had served time in prison for sodomy, not Karla. In the configuration offered by the press Aura Rosa is reconstructed as a 'lesbian,' as opposed to a 'cochona.' But what is kept rather neatly in place - following Nicaraguan social distinctions about femenina and masculina partners in same-sex women's couples - is the belief that only one partner in this homoerotic pairing is 'guilty' or doomed to stigma: la mujer masculina (the masculine woman).

According to Angelica, a lesbian and sexual rights activist with whom I spoke, Aura Rosa's representation in the press as a 'lesbian' was a sign of progress. 


\begin{abstract}
In the newspapers before, you would always see this, 'cochón this' and 'la cochona that,' even if it was not even anything about the sexuality of the person. It would be, 'this cochón robbed a woman at the market' or 'so and so, a cochona, got in a fight in a bar' . . that was the kind of thing you would see in the papers. Now it is better than it used to be. Now in the papers they use the right kind of words, 'lesbian' or 'homosexual,' instead of always these atrasado ['backward,' 'behind (the times)] terms like cochón and cochona.
\end{abstract}

Having Aura Rosa depicted as a lesbian rather than a 'dyke,' was, then, a small victory from the point of view of sexual rights activism. 'Lesbian' identity held hope as a new category of recognition, a new definition and ordering of social norms.

It was in response to Aura Rosa's murder itself, not its discursive iterations on the pages of the national papers, that sexuality activists marshaled their forces of protest. La Comisión Pro Derechos Humanos de Lesbianas y Homosexuales, Nicaragüenses (The Commission for the Human Rights of Nicaraguan Lesbians and Homosexuals), a small group of lesbian-identified women and one homosexual-identified man, leveled an activist critique of both the murder and the trial. Before Aura Rosa was killed, when the Comisión had first heard about Aura Rosa's initial imprisonment under Article 204, they visited her in her cell and recorded her life history. In the wake of her death, they aimed to provide a foil to the national press coverage and clarify what they considered essential elements of Aura Rosa's life story and her demise. [End Page 370] Eugenia, a member of the Comisión explained to me her initial reactions to the discovery of Aura Rosa's corpse.

And when they found her body...we had known her. This wasn't just whatever lesbian. It was someone who had been in prison and had had her human rights violated and here she was, dead. And no one lifted a finger, nobody in this country mobilized to see what happened with her murder. Except for us. We were there for her even in her death, like we had been when she was alive and imprisoned.

With a simple one-page-folded flyer, the Comision highlighted how Aura Rosa 'openly lived her lesbianism' and was 'unafraid of who she was' (La Comisión 2000). The pamphlet emphasized the mutual love between Karla and Aura Rosa and the duration of their relationship spanning a number of years. This time-tested and committed relationship was used to underscore something of social value in Nicaragua: a relationship that lasts. In a place where there are high rates of male abandonment of women and children ${ }^{8}$ with approximately one third of households headed solely by women, durable relationships are particularly prized. The length of Aura Rosa and Karla's relationship lent their saga a legitimating effect. It worked to emphasize that this relationship was not solely 'sexual' (read: lewd and decadent), but one based on solidly 'modern' forms of romantic love. In this case, modern love - understood as romantic, individually chosen and not necessarily procreative - could be readily juxtaposed against Karla's mother's attempt to 'sell' her daughter to the highest bidder.

The Comisión's flyer went on to interrogate the role of the Nicaraguan state in Aura Rosa's execution. ${ }^{9}$ Those who developed the wording for the document reasoned that were it not for 'prejudices,' 'repression,' and 'moralizing and destructive' laws present in Nicaragua under Article 204, Aura Rosa would have continued to 'live her life,' and her 'sexual option' as she chose. The pamphlet further charged that Aura Rosa's murderers were 'full of hate' and killed her 'because she was a lesbian.' It described that Aura Rosa's murderers felt 'justified' in their crime, and buoyed by the anti-sodomy law. Not only had Tapia and his accomplices used Article 204 to initially charge and imprison Aura Rosa, but the juridical climate engendered by the state had created the social atmosphere in which one might both imagine and carry out murder based 
on the sexuality of the victim. Moreover, the state itself was found to be largely responsible for her death. The Comisión's document explained,

\begin{abstract}
... to consider homosexuality or lesbianism as a crime is political thinking of the past century. It goes against the principle of legal equality which maintains that, [End Page 371] 'all people are born free and equal, independent of their physical, psychological, and social differences'... where is the justice? These criminals may go free despite the blood of their innocent victim: there is no Human Rights organization which defends the right to be a lesbian...we call upon all people, regardless of their sexual option to join us in solidarity and demanding justice (La Comisión 2000).
\end{abstract}

Though its circulation was limited (only a few hundred were printed due to lack of funds), the Comisión created a public denunciation with the contention that Nicaragua's legal code is retrograde, and 'of the past century.' The Comisión explicitly called for 'all people, regardless of their sexual option to join us in solidarity.' Following the logic of earlier critiques of Article 204 which claimed that the anti-sodomy law 'violated the rights of every Nicaraguan,' this particular call to action employs a strategy of inclusion. In this sense, the Comisión enlists not only a call to universal human rights, but mirrors some of the communitarian ethos of the earlier Sandinista period. The state itself is framed as a hypocritical entity that failed to guarantee the 'free and equal' status that the Nicaraguan constitution purports to uphold.

After a very brief investigation, Karla's husband, Tapia and his two accomplices were arrested and brought to trial. The prosecuting attorney for the case, Juanita Jiménez, explained, 'after each of the technical aspects [of the trial], my argument was intended to sensitize the court about how Aura Rosa's human rights were violated by these people who did not tolerate her sexual preference, nor her existence.' Jiménez asked of the court, 'what harm could Aura Rosa have done, if her only sin was to have loved a woman?' Jiménez's argument hinged on the violation of Aura Rosa's human rights, a mortal assault on her bodily integrity, and in particular, how social intolerance of Aura Rosa's sexuality prefigured this violation.

The case was won and the murderers sentenced. Jiménez concluded, 'what we've gained from this trial is the recognition that to be a lesbian is not a crime, but rather a right we have as humanas. ${ }^{10}$

Ironically the same state apparatus that had mandated Aura Rosa's incarceration because of her lesbian behavior two years prior, ultimately found that her murder - supposedly motivated by her being a lesbian - was wrong. Essentially, the court found that while engaging in same-sex sex may be designated as criminal according to current Nicaraguan law, 'being' a lesbian should not be a death sentence. Bringing international legal norms to bear upon state processes is the explicit ideological intent of human rights and here they were made to trump the state's anti-sodomy law. According [End Page 372] to Vilma, a feminist advocate, this was a triumph of the law and a sign of cultural conversion.

The society can open in this area, and it is happening. More than anything it is fear. Fear of taking on these issues. But the fact is that if you can argue for your rights in this way you don't need to be afraid. But there was internalized fear and this is why the groups [other activist groups or NGOs] didn't go forward, because they weren't sure why she was killed, for being a lesbian or what. We have prejudices inside. It is in society too. In ourselves. These men in the jury, all of them over 50 years old. And the woman in her forties. In this sense we superseded machismo and patriarchy. 
In addition to the proposition that 'machismo and patriarchy' were overcome through this process, something else came out through this trial: new ways to publicly address and acknowledge sexual rights as human rights in Nicaragua. An epistemology of a hate crime, that had been largely unimaginable in Nicaragua until rather recently, was now fully realized through Aura Rosa's murder; this constituted a new public manifestation of the category 'lesbian.'

Sexuality activists challenged the juridical culture of Nicaragua, evoking the wellcirculated parlance and persuasions of human rights in order to do so. But justice found a contradictory manifestation here. On the one hand, the state has created and maintained the hostile legal conditions which encourage the condemnation and incarceration of homosexual people. On the other hand, it is the state which must ultimately adjudicate the crime of murder, and in this case it is framed in terms of sexual discrimination. Hannah Arendt (1958), describing the aftermath of the Holocaust, understood that human rights are necessarily riddled with 'paradox' as they are dependent upon, defined by, and primarily violated by, the state. Noting a similar paradox, and speaking to the more contemporary moment of lesbian and gay human rights, Judith Butler (2004:33) writes that 'to be part of a sexual minority means, most emphatically, that we are also dependent on the protection of public and private spaces, on legal sanctions that protect us from violence, on safeguards of various institutional kinds against unwanted aggression imposed upon us, and the violent actions they sometimes instigate'. This same sort of awkward dependency on the state apparatus entreated the Comision to both appeal to, and to be appalled by, the state and the hostile environment they believe it created. For Eugenia of the Comisión, Aura Rosa's death, trial and activist interventions on her behalf served as a corrective to the Nicaraguan [End Page 373] penal code and social climate, but it served a more global purpose as well. As she put it, 'we want at least to tell the world that they are murdering lesbians in Nicaragua.'

\section{Some Lives Matter More than Others}

On the day that the United States attacked Afghanistan in reprisal for the September 11th attacks, Doña Xilo and I sat together watching television as events unfolded on CNN en Español. She observed out loud, ‘Sabes una cosa? Algunas vidas valen más que otras.' Or, 'You know something? Some lives matter more than others. ${ }^{11}$ Does Aura Rosa's life and death matter more as a 'lesbian' than as a cochona or a woman, or a person from Sandino's birthplace who lived in a mud hut?

As she is reconfigured as a semiotic reservoir for human rights and lesbian and gay advocacy on local and global levels, how does Aura Rosa's body come to embody a cause: an arbiter of moral feeling? In the last decade or so, advocates and others in Nicaragua claim that there has been increased violence against those deemed to be non-heterosexual (whether the epithet is lesbian, homosexual, gay, cochón or cochona). Larger structural changes have certainly impacted the politics of sexuality in Nicaragua including the demise of the Sandinista revolution, a series of socially conservative regimes, the global emergence of sexual rights and increasingly difficult neoliberal economic conditions where the state no longer serves its larger 'welfare' purpose. Certainly Aura Rosa's murder must be understood within a context of structural violence where grinding poverty limited the life possibilities of Aura Rosa and drove Karla Muñoz's mother to, in effect, sell her daughter to the highest bidder. 
Lesbian murders, akin to hate crimes familiar in the U.S., indicate new ways of imagining murderous intents. Indeed an epistemology of hate crimes may come to replace 'the epistemology of the closet' (Sedgwick 1990). As I have heard many times in Nicaragua, 'we have always had the cochones and the cochonas, but now we have los gays y lesbianas.' This suggests a shift from what anthropologists might call a 'folk' category, cochona, to a category which is more legible in an international register: lesbian. As Aura Rosa is made a sexual subject in the language of transnational human rights parlance, her life story is also changed: she is transformed from an economically marginalized, 'poor woman,' to a sexually marginalized, 'poor lesbian.' Rather than an agentive cochona who wooed another man's woman, Aura Rosa becomes a victim. [End Page 374]

Aura Rosa's personal history of visibility, her status as a 'well known dyke' was important in making hers a cause célèbre. As a legal vanguard, the trial provided a framework to make comparable social claims and generate narratives outside of the media and legal fray. The sensationalism of Aura Rosa's story or what Guy Debord (1977) understood as 'spectacle,' demonstrates the many seductions of visibility. The spectacle of her life, death and trial became a platform for new dialogues about sex and gender, publics and privates, martyrdom and culpability in Nicaragua and perhaps by extension, in other national settings. These juridical moves provide a legal scaffolding for others to make comparable social claims, fostering quotidian dialogues about homosexuality, human rights and 'murderous intent' in the larger collective imagination in Nicaragua.

Ultimately Aura Rosa's case underscores the power of accusation to create new terrains of cultural dialogue and potentially, transformation. Nicaraguans have a new discursive space to render experiences and opinions about 'sexuality' and sexual rights as a category of analysis. Internationally, advocacy organizations are also able to share particular narratives about the conditions and activism in Nicaragua. That Aura Rosa came to be grieved in this particular way, that her life and death was transformed through the mediums of human rights discourses, advocacy priorities, and juridical processes demonstrates the ways that a life that is 'socially vulnerable' may become valuable in its vulnerability through a politics of injury (Brown 1995). Sexual 'identity' is at one and the same time protected under the aegis of human rights, and made a spectacle as a new ontological category, one that has been 'proven' to provoke murder: making the unimaginable, imaginable.

\section{Notes}

1. For example, Nicaragua's popular national newspaper, El Nuevo Diario, has a weekly publication entitled Salud y Sexualidad (Health and Sexuality) featuring stories ranging from venereal disease to the 'origins' of homosexuality. A popular television show for youth features messages about gender, sexual, and racial equality, domestic violence, dating, pregnancy and homosexuality, among other topics. Radio shows produced in Managua air many of the same topics found in the television show. Non-governmental organizations and activist groups host discussion groups about lesbian and homosexual identity. For a comprehensive discussion of sexual rights advocacy in contemporary Nicaragua, see Howe (n.d.).

2. Nicaraguans of all ages and genders voice curiosity, and wonder out loud, about how two women could 'do it' sans penetrative genitals. Tortillera, a term used in reference to 
female/female sex is instructive. It literally means 'a female tortilla-maker' and evokes the image of two flat surfaces, eluding phallogocentrism.

3. Information about Aura Rosa's life, death and trial was gathered through a series of interviews with activists, newspaper accounts, and published materials. In order to describe the narrative efficiently, these sources have been combined with quotes and materials distinguished where necessary.

4. The text of Article 204, which was finally repealed in 2008, read thus: 'anyone who induces, promotes, propagandizes or practices in scandalous form sexual intercourse between persons of the same sex commits the crime of sodomy and shall incur 1 to 3 years imprisonment.' It also stated that if one of the parties engaging in homosexual intercourse held power or authority over the other, even if in private, s/he would be punishable with 2 to 4 years in prison for 'unlawful seduction.' International rights organizations have pointed out that Article 204 was particularly nefarious compared to other anti-sodomy laws around the world because its language allowed women to be prosecuted as well as men. Moreover, the phrasing of the legislation, 'anyone who induces, promotes, propagandizes' potentially threatens organizations, therapists, social workers and media outlets thought to be 'promoting' same-sex sexuality in their work.

5. Aura Rosa's was one of very few cases where a woman was tried and sentenced under Article 204. Activists report that when Article 204 was used to charge 'sodomy,' it was often jealous husbands, wives, or parents concerned about the sexual behavior of their daughters or sons. Among Nicaraguans who were aware of Article 204, it was commonly referred to it as a ruta de venganza; a way of exacting revenge and operationalizing state instruments for personal retribution.

6. Much might be said about the symbolic weight of disposing of Aura Rosa's body in a latrine. Putting dissidents in pit latrines (full of excrement) was one way that 'Tacho,' last of the Somoza dictators, tortured enemies of the regime; it was also a convenient and degrading way to dispose of these enemies. For Tapia to have placed Aura Rosa's body in the latrine may have evoked a similar kind of paternalist and/or patriarchal reckoning on his part - believing that, like the Somozas before him, he had the authority and 'right' to do so.

7. That the police failed to locate Aura Rosa's body quickly may signal any number of things: the life (and death) of a cochóna was of little importance, or perhaps police investigative skills and resources were tapped.

8. This recent calculation of female-headed households is from the United Nations Population Fund Survey (2004). The number of female-headed households has grown steadily since earlier waves of modernization in Nicaragua in the 1950s, with industrialization and mass migrations to the city making Managua a megalopolis. Contemporaneously, according to Nicaraguan analysts and polling, this was the onset of higher rates of male abandonment of wives (or common law wives) and children.

Nicaraguan feminists, from a less materialist vantage point, suggest that this phenomenon was only an exacerbated effect of an already-present and pervasive machista inclination to procreate and then move on.

9. To be more precise about what activists are invoking here vis-a-vis 'the state:' the Asemblea Nacional and the sitting president in 1992, Violeta Chamorro (1990-96) originally legislated the increased penalties for Article 204. Currently, the judicial branch adjudicates violations of Article 204 and in their inability (or refusal some might argue) 
to overturn the legislation, the National Assembly and the sitting President continue to be implicated in not providing the justice that activists demand.

10. Note that the feminine form of 'humans' is used here (humanas), rather than the genderneutral (according to grammatical rules) humanos which includes both males and females in the rubric of humans.

11. Doña Xilo was likely invoking her own memories of the Contra War where counterinsurgency forces, and northern aggression by the United States and its proxies levied heavy casualities among Nicaraguans as compared to the relatively few U.S. lives lost.

\section{References}

Adam, Barry. 1993. In Nicaragua: Homosexuality without a Gay World. Journal of Homosexuality, 24( 3-4) : 171-81.

Arendt, Hannah. 1958. The Origins of Totalitarianism. New York: Meridian Books.

Bolt González, Mary. 1996. Sencillamente Diferentes: La autoestima de las mujeres lesbianas en los sectores urbanos de Nicaragua. Managua, Nicaragua: Fundación Xochiquetzal.

Brown, Wendy. 1995. States of Injury: Power and Freedom in Late Modernity. Princeton: Princeton University Press.

Butler, Judith. 2004. Beside Oneself: On the Limits of Sexual Autonomy. In Undoing Gender, pp. 17-39. New York: Routledge.

Debord, Guy. 1977. The Society of the Spectacle. Detroit: Black and Red.

- 1988. Comments on the Society of the Spectacle. Trans. Malcolm Imrie. New York: Verso.

El Nuevo Diario. 2000. 'Lesbiana tuvo una vida tormentosa,' Edwin Somarraba, February 27.

Elliston, Deborah A. 1995. Erotic Anthropology: 'Ritualized Homosexuality' in Melanesia and Beyond. American Ethnologist, 22( 4 ): 848-867.

Ferguson, Ann. 1991. Lesbianism, Feminism and Empowerment in Nicaragua. Social Review, 21(3) : 75- 97.

Foucault, Michel. [1978] 1990. The History of Sexuality, Volume I. New York: Vintage.

Franke, Katherine M. 2002. Putting Sex to Work. In Left Legalism/Left Critique, edited by Wendy Brown \& Janet Halley, pp. 290-336. Durham: Duke University Press.

Howe, Cymene. n.d. Mediating Sexuality: Activists and the Politics of Sexual Rights in Nicaragua (forthcoming). Durham: Duke University Press.

La Boletina. 2004. Managua, Nicaragua: Puntos de Encuentro.

La Comisión. 2000. (La Comisión Pro Derechos Humanos de Lesbianas y Homosexuales, Nicaragüenses [The Commission for the Human Rights of Nicaraguan Lesbians and Homosexuals]. Managua, Nicaragua: photocopy document.

Lancaster, Roger. 1992. Life is Hard: Machismo, Danger and the Intimacy of Power in Nicaragua. Berkeley: University of California Press.

La Prensa. 2000. 'Condenan a tres por muerte de Masatepina,' Leopoldo Arias; edición 22054, June 28.

Montenegro, Sofía. 2000. La Cultura Sexual en Nicaragua. Managua, Nicaragua: cinco (Centro de Investigaciones de la Comunicacion).

Nagengast, Carole \& Terrence Turner. 1997. Universal Human Rights versus Cultural 
Relativity. Journal of Anthropological Research, 53(4) : 269-72.

Randall, Margaret. 1993. To Change Our Own Reality and the World: A Conversation with Lesbians in Nicaragua. Signs, Special Issue: Theorizing Lesbian Experience, 18(4) : 907924.

Sedgwick, Eve Kosofsky. 1990. Epistemology of the Closet. Berkeley: University of California Press.

St. Augustine. 2006. Confessions. Trans. Garry Wills. New York: Penguin Classics. Thayer, Millie. 1997. Identity, Revolution and Democracy: Lesbian Movements in Central America. Social Problems, 44(3): 386 -406.

United Nations Population Fund. 2004. 'Investing in People: National Progress in Implementing the ICPD Programme of Action 1994-2004,' Issue 32. http://www. unfpa.org/ publications/detail.cfm?ID=179\&fi lterListType=, accessed 2 June 2007.

World Organisation Against Torture. Violence against Women in Nicaragua, 1 January 2001. Online. UNHCR refworld, available at http://www.unhcr.org/refworld/docid/ 46c190970.html [accessed 22 March 2009].

Žižek, Slavoj. 2005. Against Human Rights. New Left Review 34 (July-August). Electronic document, http://newleftreview.org/?page=article\&view=2573, accessed 22 February 2007. 